\title{
Kekerasan Terhadap Anak dan Perempuan
}

\author{
Anwar Hidayat \\ Institut Agama Islam Negri (IAIN) purwokerto \\ *) Correspondence Author, e-mail: elanwar290701@gmail.com
}

\begin{abstract}
Abstrak: Kekerasan yang terjadi terhadap anak dan perempuan tanpa kita sadari sering dilakukan oleh orang orang dewasa. Padahal mereka adalah orang yang memiliki tugas sebagai pelindung anak dan perempuan yang paling utama. Parahnya sebuah survei menyatakan $60 \%$ wanita (ibu ) lebih sering melakukan kekerasan dari pada laki laki (ayah). begitu pula dengan tindak kekerasan terhadap perempuan,yang dimana kebanyakan yang menjadi pelaku adalah orang orang yang berada paling dekat dengan mereka, seperti ayah dan juga suami. Terdapat beberapa hal yang melatar belakangi mengapa kekerasan terhadap anak lebih banyak dilakukan oleh seorang ibu, diantaranya adalah stress dan juga kenangan masa lalu yang suram. Kekerasan terhadap anak dan perempuan itu dapat menyebabkan berbagai macam dampak negatif, diantaranya ialah fisik maupun psikis. Bahkan kekerasan terhadap anak dan perempuan itu memiliki dampak yang sangat berbahaya, yaitu dapat menyebabkan kematian terhadap korban. Dampak lainnya yang juga berbahaya ialah trauma yang berkepanjangan, dikhawatirkan hal tersebut akan memicu adanya pengulangan tindakan kekerasan yang pernah dialaminya, yang menjadi korban adalah anak anak mereka dimasa depan. Pelaku tindakan kekerasan ditindak tegas dalam peraturan perundangundangan. peraturan tidak memandang bulu, walaupun pelaku adalah orang tuaq sendir tetap di tindak dengan tegas guna meminimalisir dan juga menghentikan tindakan kekerasan yang kerap terjadi.
\end{abstract}

Kata kunci: Kekerasan, anak, perempuan

Article History: Received on 02/03/2020; Revised on 08/06/2020; Accepted on 12/06/2020; Published Online: 11/7/2020.

This is an open access article distributed under the Creative Commons Attribution License, which permits unrestricted use,
distribution, and reproduction in any medium, provided the original work is properly cited. (C2020 by author.

\section{PENDAHULUAN}

Retirement Salah satu tindak kejahatan yang menjadi fenomena akhir-akhir ini adalah kekerasan seksual terutama terjadi terhadap anak-anak. Anak adalah anugerah yang tak ternilai yang dikaruniakan oleh Tuhan pada setiap pasangan manusia untuk dipelihara, dilindungi, dan dididik dengan baik. Ia adalah manusia yang mempunyai kemampuan fisik, mental, dan sosial yang masih terbatas untuk mengatasi berbagai resiko dan bahaya yang dihadapinya dan juga secara otomatis masih bergantung pada pihak-pihak lain terutama anggota keluarga yang berperan aktif untuk melindungi dan menjaganya. Perlindungan terhadap hidup dan penghidupan anak masih menjadi tanggungjawab kedua orangtua, keluarganya, masyarakat dan juga negara. Perlindungan ini dapat berupa pemenuhan kebutuhan sandang, pangan, dan papan. Tidak hanya itu, perlindungan yang diberikan terhadap seorang anak juga dapat berupa perlindungan 
terhadap kondisi psikologis atau mental dari anak yaitu terutama perkembangan kejiwaannya.

Dalam pandangan islam kekerasan itu dilarang, Indonesia sebagai negara dengan penduduk muslim terbanyak memiliki kasus kekerasan yang tinggi. Deputi Bidang Perlindungan Anak Kementerian Pemberdayaan Perempuan dan Perlindungan Anak (Kemen PPPA), Nahar mengatakan, sejak Januari hingga 31Juli 2020 tercatat ada 4.116 kasus kekerasan pada anak di Indonesia.Menurut dia, dari angka tersebut yang paling banyak dialami oleh anak adalah kekerasan seksual.Hal itu ia katakan berdasarkan data Sistem Informasi Online Perlindungan Perempuan dan Anak (Simfoni PPA) sejak 1 Januari hingga 31 Juli 2020."Dari angka ini (4.116 kasus), angka yang paling tinggi itu angka korban kekerasan seksual.

Kurangnya kesadaran dan rendahnya pendidikan berpotensi menimbulkan tindak kekerasan seksual. Tanggung jawab orang tua terhadap anak sangat penting dibandingkan dengan orang lain, namun harus ada dukungan masyarakat dalam menjaga antar sesama dan peduli dengan masalah kekerasan ini agar dapat mencegah kekerasan seksual terhadap anak. Maka dari itu harus ada upaya untuk mangajak orang tua agar mengajarkan pendidikan seksual yang baik pada anak dan meningkatkan kesadaran masyarakat tentang pentingnya menjaga anak dari kekerasan seksual.

Kekerasan seksual pada anak dapat terjadi di waktu, tempat dan pelaku yang tak terduga. Namun pelaku kekerasan seksual pada anak umumnya adalah orang yang dikenal anak (66\%) termasuk orang tuanya sendiri (7,2\%) (Paramastri, 2010: h.2). Fakta tersebut menunjukan bahwa pelaku kekerasan seksual pada anak kebanyakan bukan dari orang lain yang belum pernah dikenal anak melainkan sebaliknya. Huraerah (2012) menjelaskan bahwa kekerasan seksual sering terjadi di rumah $(48 \%)$, tempat umum $(6,1 \%)$, sekolah $(4,1 \%)$, tempat kerja $(3,0 \%)$, lain- lain $(0,4 \%)$. Hal ini menunjukan bahwa rumah merupakan tempat yang pada umumnya sering dijadikan tempat kekerasan tersebut.Jika masalah ini terus dibiarkan, maka jumlah kasus seksual pada anak akan terus mengalami peningkatan dan akan berdampak buruk bagi anak. Dampak dari kekerasan seksual secara fisik dapat berupa luka pada bagian intim anak, Dampak psikologi meliputi trauma mental, ketakutan, malu, kecemasan bahkan keinginan atau percobaan bunuh diri. Selain itu dampak sosial yang akan dialami anak adalah perlakuan sinis dari masyarakat di sekelilingnya dan takut untuk berinteraksi. Kekerasan seksual terhadap anak akan menjadi trauma yang berkepanjangan hingga dewasa, disamping itu kekerasan seksual terhadap anak akan berdampak pada masalah kesehatan di kemudian hari.

Berangkat dari latar belakang masalah tersebut maka penulis menawarkan pendekatan keterkaitan kekerasan dengan hukum agama. Dalam khazanah Islam, tindak kekerasan adalah tindakan penganiayaan atau perbuatan dzalim kepada orang lain yang dilarang,penulis dengan ini mengharapkan kekerasan seksual dapat diminimalisir bahkan bisa dicegah. 


\section{PEMBAHASAN}

Sejak kecil kita semua telah mengenal berbagai macam bentuk kekerasan, baik kekerasan terhadap ana maupun kekerasan terhadap perempuan. Kekerasan tersebut berupa kekerasan verbal, kekerasan fisik bahkan kekerasan seksual. Kekerasan sudah sangat melekat dengan diri kita sejak kecil. Kekerasan bisa menimpa siapa saja, kapan saja dan dimana saja.Tindakan kekerasan adalah tindakan fisik baik dengan sengaja maupun dalam bentuk lainnya seperti ancaman ataupun perbuatan lainnya terhadap orang yang dapat menyebabkan cidera, depresi, kerugian psikologi bahkan kematian. Kekerasan terhadap anak ialah segala perbuatan yang dapat menimbulkan suatu kesengsaraan dan penderitaan baik secar fisikfisik, mental, seksual, psikologis termasuk perlakuan yang merendahkan martabat anak.

Definisi kekerasan terhadap anak menurut WHO mencakup semua bentuk perlakuan yang salah baik secara fisik dan/atau emosional, seksual, penelantaran, dan eksploitasi yang berdampak atau berpotensi membahayakan kesehatan anak, perkembangan anak, atau harga diri anak dalam konteks hubungan tanggung jawab. Berdasarkan definisi tersebut, kekerasan anak dapat berupa kekerasan fisik, kekerasan seksual dan kekerasan emosional atau psikis. Kekerasan fisik terhadap anak merupakan kekerasan yang kemungkinan besar terjadi. Termasuk dalam kekerasan fisik adalah ketika seseorang menggunakan anggota tubuhnya atau obyek yang bisa membahayakan seorang anak atau mengontrol kegiatan/tindakan anak. Kekerasan fisik dapat berupa mendorong, menarik rambut, menedang, menggigit, menonjok, membakar, melukai dengan benda, dan jenis kekerasan fisik lain termasuk membunuh. Kekerasan terhadap anak juga dapat dipandang dari sisi perlindungan anak.

UNICEF mendefiniskan 'perlindungan anak' sebagai cara yang terukur untuk mencegah dan memerangi kekerasan, eksploitasi, memperlakukan tidak semestinya terhadap anak termasuk eksploitasi seksual untuk tujuan komersial, perdagangan anak, pekerja anak dan tradisi yang membahayakan anak seperti sunat perempuan dan perkawinan anak. Dalam kontek tersebut jelas bahwa kekerasan anak tercermin dalam berbagai aspek terkait perlindungan anak sesuai dengan definisi dari UNICEF. Jenis kekerasan terhadap anak berikutnya adalah kekerasan seksual dan psikis. Kekerasan seksual terhadap anak mencakup beberapa hal seperti menyentuh anak yang bermodus seksual, memaksa hubungan seksual, memaksa anak untuk melakukan tindakan secara seksual, memperlihatkan bagian tubuh untuk dipertontonkan, prostitusi dan eksploitasi seksual, dan lain-lain. Selanjutnya kekerasan psikis terjadi ketika seseorang menggunakan ancaman dan menakut- nakuti seorang anak termasuk mengisolasi dari keluarga dan teman. Kekerasan yang juga sangat dekat dengan kekerasan psikis adalah kekerasan emosional melalui perkataan atau perbuatan yang membuat anak merasa bodoh atau tak berharga. Kekerasan emosional mencakup antara lain mengkritik terus menerus, menyalahkan semua masalah keluarga kepada anak, memalukan anak di depan orang lain, intimidasi, dan lain-lain.

Kekerasan seksual pelakunya bisa guru/dosen, tenaga pendidik, tokoh agama yang berperan sebagai pendidik, tokoh masyarakat, guru besar/professor, teman, pacar, teman, pejabat stuktural sekolah/kampus, pihak luar sekolah/kampus yang berperan membantu Terselenggaranya pendidikan. Fakta menemukan bahwa kebanyakan pelaku kekerasan seksual adalah orang-orang yang dikenal oleh korban. 
Kekerasan terhadap anak yang dilakukan oleh orang tua yang stress antara lain: (1) Kekerasan fisik yaitu merupakan segala tindakan yang dapat mengakibatkan kerusakan yang dapat dilihat seperti memukul, menendang, menusuk, menyayat, menampar dan lain lain. Seringkali semua orang tua tidak mampu menahan emosi mereka ketika anak tidak patuh dan sering membuat marah mereka, orang tua Sering sekali meresponnya dengan tindakan fisik, seperti memukul, mencubit, menendang, menjewer dan lain sebagainya. Mereka tidak sadar atas apa yang mereka lakukan terhadap anak anak mereka. Seharusnya orang tua menanggapi perilaku anak mereka yang nakal dengan cara kasih sayang, dengan cara seperti itu anak akan lebih mudah untuk menyadari kesalahannya. (2) Kekerasan psikologis yang mengarah kepada tindakan yang dapat mengintimidasi dan mengancam. tidak peduli, menghina, mengisolasi, penolakan dan teror merupakan bagian dari klasifikasi kekerasan psikologis. Orang tua pada masa sekarang ini banyak yang tidak peduli terhadap anaknya sendiri, diera globalisasi ini teknologi semakin canggih. mereka lebih sibuk dan asik bermain gadget yang semakin melupakan kewajiban orang tua terhadap anak. (3)Kekerasan seksual yang sering terjadi pada anak anak, merek dipaksa dan diancam untuk melakukan tindak seksual yang tidak mereka inginkan. Kekerasan seksual sering terjadi dilingkungan keluarga yang kurang akan pendidikan, jika seorang anak mengenal seks tanpa disertai edukasi yang baik, otak anak akan rusak karena mengalami kecanduan terhadap segala sesuatu yang berbau seksual. Hal seperti ini dapat mengganggu atau bahkan menghancurkan masa depan anak tersebut. (4)Kekerasan ekonomi adalah kekerasan yang berupa tindakan tindakan penolakan kebutuhan dasar anak. Kebutuhan makanan dan gizi anak tidak terpenuhi secara maksimal, hal tersebut dapat mengganggu pertumbuhan anak, sehingga anak akan kesulitan dalam menggapai masa depannya

Faktor faktor penyebab kekerasan terhadap anak diantaranya ialah (1) Pernikahan usia muda,hal ini menjadi salah satu penyebab terjadinya kekerasan, hal ini disebabkan karena orang yang melakukan pernikahan usia muda belum siap menjadi pembimbing bagi anak anak mereka. Orang tua yang menikah pada usia muda masih memiliki keinginan untuk merasakan kebebasan, dan merek belum tau apa tanggung jawab mereka terhadap Anak anak mereka. (2)Kurangnya ilmu, orang tua yang memiliki kekurangan dalam ilmu tidak dapat menangani dan memahami fase pertumbuhan dan kebutuhan anak. Mereka lebih sering melakukan tindakan yang berbau kekerasan tanpa memikirkan dampak yang ditimbulkan terhadap psikologi anak. (3) Masalah ekonomi,orang tua yang memiliki permasalahan dalam ekonomi kurang memperhatikan kebutuhan anaknya. Bahkan ada orang tua yang mengeksploitasi anaknya demi memenuhi kebutuhan ekonomi keluarga. (4) Konflik keluarga, konflik antara suami dan istri sering terjadi dalam kehidupan sehari-hari. Hal tersebut berpengaruh terhadap emosi orang tua yang sulit dikontrol, bahkan orang tua yang sedang mengalami konflik bisa saja melampiaskan kemarahannya terhadap anak. (5) Perceraian, banyak terjadi pada pasangan suami istri yang mengalami masalah, orang yang mengalami perceraian akan memiliki tanggung jawab yang lebih besar. Hubungan dengan anak bisa menjadi renggang dan anak akan menemukan jati diri mereka dengan cara pergaulan yang salah. (6) Kegagalan dalam bersosialisasi dengan masyarakat, kegagalan orang tua untuk bersosialisasi dengan masyarakat akan menyebabkan pengucilan terhadap keluarga tersebut. Hal ini akan berdampak juga terhadap anak, anak akan dikucilkan oleh teman temannya bahkan anak anak akan mendapatkan perlakuan kekerasan. (7) Luka 
batin, orang tua yang memiliki luka batin akan sulit membedakan mana tindakan yang salah dan mana tindakan yang benar. Mereka akan cenderung lebih emosional dan hal tersebut akan berdampak buruk bagi anak anaknya.

\section{Kekerasan terhadap anak yang dilakukan orang tua dimasa pandemi covid 19}

Kekerasan terhadap anak pada masa pandemi covid 19 dimulai pada saat pemerintah menerapkan PSBB terhadap masyarakat. Pemerintah menganjurkan masyarakat untuk tetap berada di rumah dan menggunakan protokol kesehatan dalam rangka memutuskan mata rantai virus covid 19. Kekerasan terhadap anak terjadi karena dua faktor, yang pertama ialah konflik yang terjadi anatar orang tua dengan anaknya. Kedua ialah faktor ekonomi yang semakin menurun yang terjadi akibat covid 19.

Upaya yang dapat dilakukan guna meminimalisir kekerasan tersebut diantaranya: 1)Saling memberi pemahaman bahwasanya setiap anak berhak mendapatkan perlindungan dari orang tua,2) Orang tua harus meningkatkan rasa kepedulian terhadap anak mereka.3) Pemerintah harus lebih tegas dalam menegakkan hukum.

Teori tentang penyebab tindak kekerasan terhadap perempuan diambil dari literatur tentang agresi dan kekerasan umum. Baik penelitian tentang kekerasan umum maupun kekerasan terhadap perempuan menunjukkan bahwa kekerasan timbul dari interaksi antara faktor sosial dan psikososial individu dan proses sosial (misalnya Reiss dan Roth, 1993). Tetapi yang jelas bahwa faktor penyebab terjadinya kekerasan bisa sangat kompleks. Hosking (2005) menyebutkan bahwa secara umum penyebab terjadinya tindak kekerasan dapat dikelompokkan menjadi dua yaitu faktor individu dan faktor sosial. Faktor individu berkaitan erat dengan kecendrungan individu untuk berbuat kekerasan. Sementara itu, faktor sosial merupakan kondisi lingkungan yang mendorong seseorang berbuat kekerasan.

\section{Faktor individu}

Dari sisi psikologis, motivasi utama untuk melakukan tindak kekerasan dapat dipandang sebagai ketidakmampuan untuk menahan emosi, bahkan kekerasan digunakan media mengeskpresikan perasaan seseorang seperti marah, frustasi atau sedih (Jacobson 2011). Kesulitan mengontrol emosi sering menjadikan seseorang berbuat kekerasan. Perilaku kekerasan terkadang juga disebabkan karena orang tumbuh di lingkungan dimana kekerasan sering dipertontonkan, sehingga kekerasan dipahami sebagai perilaku yang wajar. Terkadang kekerasan yang dilakukan individu digunakan sebagai cara-cara memengaruhi orang lain untuk mengendalikan situasi.

Beberapa faktor yang melekat pada individu pelaku kekerasan juga dapat dipengaruhi oleh berbagai hal seperti pengaruh teman sejawat, kurang perhatian, merasa tidak berharga keberadaannya, pernah mengalami perlakuan buruk, dan menyaksikan kekerasan di rumah atau di luar rumah.Menurut Hosking (2005), faktor utama akan kecenderungan seseorang untuk berbuat kekerasan adalah kurangnya rasa empati. Meskipun seorang bayi yang lahir dipenuhi kapasitas empati pada dirinya, akan tetapi tumbuhnya rasa empati tersebut bergantung pada apa yang dia pelajarai dan lihat dari reaksi orang dewasa terhadap penderitaan atau rasa sakit orang lain. 


\section{Faktor Sosial Budaya}

Kondisi sosial yang dapat mendorong terjadinya kekerasan sering merefleksikan adanya ketimpangan sosial atau ekonomi antar kelompok masyarakat. Terkait dengan kekerasan terhadap perempuan Hosking (2005) menyatakan bahwa sejumlah penelitian mengidentifikasi keterkaitan antara ketimpangan gender dengan tingkat kekerasan terhadap perempuan. Jacobson (2011) mengidentifikasi beberapa faktor sosial yang mungkin menciptakan kondisi yang mengantarkan pada terjadinya kekerasan antara lain: a) Sikap permisif masyarakat akan kekerasan terhadap perempuan, b) Kontrol lakilaki dalam pengambilan keputusan dan pembatasan terhadap kebebasan perempuan c) Identitas dan peran laki-laki dan perempuan yang kaku di masyarakat d. Hubungan antar sesama yang merendahkan perempuan e) lingkungan kumuh dan padat penduduk f) Keterpaparan pada kekerasan.

\section{Kekerasan terhadap perempuan}

Kekerasan terhadap perempuan merupakan realita yang terjadi sepanjang masa. Hal yang telah terjadi ini, juga menarik perhatian untuk dibicarakan. Banyak media yang digunakan dari agama, budaya sampai persoalan sosial politik. Akibatnya, sikap yang timbul menjadi lebih beragam antara satu dengan yang lain, pendekatan dan teorinya juga berbeda beda keinginan untuk melindungi hak-hak perempuan menyebabkan munculnya gerakan lembaga atau organisasi, Pelanggaran seperti pelecehan seksual yang sering terjadi di masyarakat, telah diatur dalam undang-undang hukum pidana. peran lembaga yang turut melindungi hak-hak kaum perempuan dari tindak kerkerasan bisa kita lihat. Persoalanya, terkadang perlindungan hukum terhadap kaum perempuan kurang menjangkau rumah tangga. Bahkan yang sering melakukan tindak kekerasan tersebut merupakan suaminya sendiri. Dengan hal ini kita bisa mengetahui bahwa adanya pemahaman yang kurang tentang hak dan kewajiban.

Kondisi pada masa lalu, tidak mutlak diterapkan pada masa sekarang. Kita boleh mengaplikasikan konsep keagamaan dalam bingkai kekinian. Salah satu penyebabnya tindak kekerasan terhadap perempuan, adalah dominannya penafsiran yang salah yang sering dilakukan oleh kaum laki-laki. Sekalipun agama secara mutlak tidak pernah membedakan kedudukan laki-laki dan perempuan, penafsiran terhadapnya sangat rentan mengarah kepada kedudukan perempuan. Agama dengan begitu sering dijadikan sebagai sebuah dalil kekerasan terhadap perempuan. Parahnya, saat bertemunya agama dengan budaya, hal ini sudah menjadi barang baku yang tidak bisa dipertentangkan.

Pada hakikatnya agama tidak mengajarkan kezaliman atau kekerasan.oleh karena itu agama harus menjunjung keadilan, sekalipun budaya pada hakikatnya adalah produk manusia dan karena itu pula budaya dapat dirubah. Dalam asumsi penulis, aplikasi keagamaan perlu dilakukan dalam situasi kekinian. penafsiran konsep atau teks, perlu disesuaikan dengan masa saat ini. Dalam situasi ini,para tokoh agama sangat berperan penting dalam memberikan ajaran terhadap masyarakat. Selain itu para tokoh agama juga harus mampu melakukan pendekatan budaya. peranan tokoh agama bisa memuaskan segala pihak yang terlibat. 
Tindak kekerasan terhadap perempuan sering dilihat dari satu sisi agama, kekerasan dalam rumah tangga yang dialasi dengan agama sangat merugikan perempuan. Dalam hal inilah, konsep pluralisme beragama menemukan bentuknya dengan konsep hukum positif bangsa Indonesia. Pemilihan gender sebagai salah satu permasalahan yang mewarnai wacana pemikiran Islam, menuju asumsi bahwa persoalan ini memang sangatlah menarik untuk dikaji. Bukan hanya karena permasalahan gender adalah suatu elemen yang penting dalam struktur masyarakat,akan tetapi karena di dalamnya terdapat elemen-elemen lain yang cukup bersangkut paut dengan agama, politik dan budaya. Permasalahan gender dalam pemikiran Islam muncul karena adanya kesadaran dalam memahami sebuah wawasan Islam tentang perempuan.

Mengomentari hal di atas, Nurcholis Madjid mengatakan bahwa permunculan masalah perempuan adalah absah, otentik dan sejati. Ia juga mengatakan bahwa Islam pemuncul masalah ini, juga terasa bersifat emosional, apologi, ideologis dan tidak jarang subjektif, sekalipun menurut Cak Nur memancarkan perenungan dan pemikir kreatif orisinal. Seperti diketahui, dalam pandangan sosiologis, agama tidak hanya dilihat secara ideologis sebagai kepercayaan terhadap Tuhan, akan tetapi juga dilihat secara praktis sebagai sebuah peribadatan. Agama adalah salah satu struktur institusional penting yang melengkapi keseluruhan sistem sosial. Atau dengan kata lain, fungsi sosial agama merupakan faktor yang sangat menentukan berlangsungnya sistem sosial. Signifikansi tersebut dapat dilihat dari adanya tujuan keberagamaan yang dilakukan manusia; misalnya untuk mendapatkan kebahagiaan, ketenangan dan keteraturan. Oleh karena itu, dalam pandangan sosiologis, masyarakat dianggap sebagai suatu "lembaga" sosial yang berada dalam keseimbangan yang merupakan kegiatan manusia berdasarkan normanorma yang dianut bersama serta dianggap sah dan mengikat peran serta manusia itu sendiri. muncul karena adanya sebuah penafsiran terhadap Kitab Suci yang berbicara tentang kedudukan laki-laki dan perempuan. Dalam al-Quran, misalnya, Tuhan mengatakan bahwa "laki-laki adalah pemimpin bagi perempuan". Dalam beberapa kasus, kedudukan perempuan dianggap berada di bawah laki-laki,hal ini sering dijadikan sebuah alasan menganggap bahwa seorang laki-laki lebih tinggi dibandingkan perempuan. Pendapat ini berdasarkan pemahaman bahwa agama telah memberikan keistimewaan terhadap laki-laki yang berbeda dengan apa yang dimiliki oleh perempuan.

Secara sosiologis, pemberian tersebut telah memunculkan sikap dan pemahaman terhadap budaya patriarki. Islam merupakan agama yang diturunkan di tanah Arab, Sebagai agama yang menjunjung prinsip kesetaraan, Islam menegaskan bahwa manusia yang paling mulia adalah mereka yang paling bertakwa kepada allah SWT. Menurut penulis, penafsiran terhadap teks-teks Kitab Suci seperti disebutkan dalam kasus ini, sering dijadikan justifikasi terhadap suatu realitas. Dalam keadaan seperti ini, kita menemukan sebuah pertentangan terhadap penafsiran yang dianggap berat sebelah. Fatimah Mernissi, Nawal Sa'adawi dan Aminah Wadud Muhsin, serta beberapa nama yang bersifat lokal di Indonesia seperti Wardah Hafidz, Lies Marcoes Natsir dan Siti Ruhaini, berusaha membongkar berbagai macam pengetahuan yang normative.

Pandangan klasik Islam yang membuat subordinasi terhadap perempuan dalam berbagai sektor, tidak diterima secara tegas oleh kaum feminis. Penolakan yang didasari karena pertimbangan ideologis tersebut dilakukan untuk menghilangkan kecenderungan 
penerapan sifat-sifat keperempuan (female medest) seperti emosional, penurut dan milik laki-laki. Penerapan ini juga yang kemudian menimbulkan implikasi sosiologis dan membawa kaum perempuan kepada posisi ditindas, dianiaya dan dizalimi. Terdapat banyak kasus dari kecenderungan subordinasi ini membuat perempuan diperlakukan secara tidak adil oleh laki-laki yang mengatasnamakan agama. penganiayaan terhadap istri bisa dianggap sebagai suatu tindak kekerasan terhadap perempuan.

\section{Bentuk bentuk kekerasan seksual}

Bentuk kekerasan seksual antara lain 1) Pemerkosaan yang merupakan tindakan pemaksaan seksual yang menggunakan alat kelamin laki-laki ke alat kelamin perempuan. Perkosaan adalah konspirasi politik patriarkis. Sistem patriarki menempatkan perempuan sebagai makhluk kelas dua. Posisi perempuan sebagai subordinat bermula dari konsep dikotomik atau oposisi biner. 2) Intimidasi seksual yaitu Tindakan intimidasi seksual akan berpengaruh terhadap psikis korban. 3) Pelecehan seksual yaitu tindakan fisik dengan sasaran bagian seksual korban. 4) Prostitusi, merupakan tindakan dimana perempuan dipaksa sebagai pekerja seksual. 5) Pemaksaan aborsi yaitu tindakan yang memaksa untuk menggugurkan kandungan.

Komitmen pemerintah dalam melindungi perempuan dan anak ditunjang oleh peraturan perundang-undangan. Sejumlah undang-undang yang mendukung program mengakhiri kekerasan terhadap perempuan dan anak antara lain Undang-Undang Dasar 1945, Undang-Undang Nomor 4 Tahun 1979 tentang Kesejahteraan Anak, Undang-Undang Nomor 29 Tahun 1999 tentang Ratifikasi Penghapusan Diskriminasi Rasial,Undang-Undang Nomor 39 Tahun 1999 tentang Hak Azasi Manusia, UndangUndang Nomor 1 Tahun 2000 tentang Pengesahan Konvensi ILO Nomor 182, UndangUndang Nomor 23 Tahun 2002 tentang Perlindungan Anak, Undang-Undang Nomor 13 Tahun 2003 tentang Ketenagakerjaan, Undang-Undang Nomor 20 Tahun 2003 tentang Sistem Pendidikan Nasional, dan Undang-Undang Nomor 23 Tahun 2004 tentang Penghapusan Kekerasan Dalam Rumah Tangga. Kemudian untuk UndangUndang Nomor 23 Tahun 2002 tentang Perlindungan Anak diperbaharui dan dirubah dengan Undang-Undang Nomor 35 Tahun 2014.

Perlindungan yang dilakukan oleh pemerintah terhadap anak dan juga perempuan dilakukan oleh Kementerian Pemberdayaan Perempuan dan Perlindungan Anak serta kementerian dan lembaga terkait. Agar kekerasan terhadap anak dan perempuan dapat berakhir, pemerintah perlu mengambil tindakan tindakan yang dapat menghentikan kekerasan yang terjadi. Diantaranya ialah : 1) Menjamin informasi hak aperempuan dan anak yang menjangkau seluruh masyarakat Indonesia. 2) Memastikan berfungsinya kelembagaan di tingkat desa untuk menjamin pemenuhan hak perempuan dan anak. 3) Memastikan berfungsinya Satgas Perlindungan Perempuan dan Anak di daerah. 4) Menggalang dukungan yang masif dari pemangku kepentingan.

Perlindungan terhadap wanita adalah suatu upaya dalam melindungi hak hak seorang wanita, terutama untuk memberikan sebuah rasa aman dalam pemenuhan hakhaknya dengan memberikan perhatian yang konsisten dan sistematik yang pada hakekatnya ditujukan untuk mewujudkan keadilan dan kesetaraan gender.

Dalam Undang-undang Nomor 23 tahun 2004, pemerintah berupaya menghapus kekerasan khususnya kekerasan terhadap perempuan yang terjadi dalam rumah tangga. 
Kekerasan terhadap perempuan dalam Undang-undang tersebut didefinisikan sebagai setiap perbuatan terhadap seseorang terutama perempuan, yang berakibat timbulnya kesengsaraan atau penderitaan secara fisik, seksual, psikologis, dan/atau penelantaran rumah tangga termasuk ancaman untuk melakukan perbuatan, pemaksaan, atau perampasan kemerdekaan secara melawan hukum dalam lingkup rumah tangga. Dalam undang-undang tersebut, penghapusan kekerasan dalam rumah tangga bertujuan untuk mencegah segala bentuk kekerasan dalam rumah tangga, melindungi korban kekerasan dalam rumah tangga, menindak pelaku kekerasan dalam rumah tangga, dan memelihara keutuhan rumah tangga yang harmonis dan sejahtera.

Berikut ini adalah kekerasan yang dilakukan oleh pasangan dan anggota keluarga : 1) Kekerasan ekonomi termasuk tindakan menolak memberikan uang belanja, menolak memberikan makan dan kebutuhan dasar, dan mengendalikan akses terhadap pekerjaan. 2)Kekerasan seksual seperti pemaksaan hubungan seksual melalui ancaman, intimidasi atau kekuatan fisik, memaksakan hubungan seksual yang tidak diinginkan atau memaksa hubungan seksual dengan orang lain. 3) Kekerasan fisik seperti menampar, memukul, memutar lengan, menikam, mencekik, membakar, menendang, ancaman dengan benda atau senjata, dan pembunuhan. Ini juga termasuk praktek berbahaya bagi perempuan seperti mutilasi alat kelamin perempuan 4) Kekerasan psikologis yang meliputi perilaku yang dimaksudkan untuk mengintimidasi dan menganiaya, dan bentuk ancaman berupa ditinggalkan atau disiksa, dikurung di rumah, ancaman untuk mengambil hak asuh anakanak, penghancuran benda-benda, isolasi, agresi verbal dan penghinaan terus menerus.

Sumber yang paling utama dalam islam adalah al Quran, al Quran merupakan sebuah kitab yang didalamnya berisi sebuah petunjuk. Al Quran sendiri bukanlah sebuah Kitab sains dimana akan berbahaya apabila menyandingkannya dengan sains. Epistemologi keilmuan Islam akan menjawab pertanyaan pertanyaan ilmiah yang ada didalam al Quran. Kajian kajian perilaku keagamaan umat muslim yang dilakukan oleh Frederick M denny, pendekatan sosiologis yang terlalu sosiologis kurang memiliki kedalaman pemaknaan ajaran dan ekspresi keagamaan yang lahir dalam ajaran ajaran tersebut.

Islam secara tegas dan jelas melarang kekerasan terhadap anak. Tetapi ada salah satu hadist mengatakan "Perintahkanlah anak-anakmu untuk solat ketika mereka berumur tujuh tahun. Pukulah mereka jika sampai berusia sepuluh tahun mereka tetap enggan untuk melaksanakan solat" (Abu Daud:495 dan Ahmad:6650, dishahihkan oleh Al-Albany dalam Irwa'u Ghalil, no. 247). Hadist tersebut tentunya bertentangan dengan konsep bahwa anak tidak boleh mendapatkan kekerasan. Namun, adanya hadist ini bukanlah semata-mata tanpa adanya alasan yang jelas. Hukuman fisik diberikan bukan hukuman yang dapat menimbulkan efek trauma dan cidera pada anak. Kekerasan anak dalam islam diperbolehkan jika tidak melebihi batas dan digunakan sebagai langkah akhir yang ditempuh. Kekerasan ini akan dilakukan jika dirasa tidak ada lagi hukuman yang dapat membuat anak jera. Hal ini juga hanya digunakan sebagai upaya yang mendidik bukan dengan tujuan untuk menghukum tanpa alasan. Karena jika anak dibiarkan bebas tanpa aturan, maka akan berdampak buruk bagi anak. Anak bisa menyimpang dari aturan agama, bertindak semaunya, dan perilaku negatiflainnya. Jadi kesimpulannya, kekerasan anak dalam Islam tidak diperbolehkan kecuali dalam 
kondisi yang darurat dan tidak ada cara lain lagi. Namun itupun harus dilakukan dengan syarat hukuman tersebut bersifat ringan dan tidak menganiaya. Islam lebih menganjurkan untuk memperlakukan anak-anak dengan kasih sayang dan pemahaman nilai agama semenjak dini. Dengan begitu anak pun tumbuh menjadi pribadi yang berakhlaqul karimah.

\section{KESIMPULAN}

Berdasarkan pembahasan yang telah dipaparkan, maka dapat disimpulkan bahwa pada hakikatnya agama tidak mengajarkan kezaliman atau kekerasan.oleh karena itu agama harus menjunjung keadilan, sekalipun budaya pada hakikatnya adalah produk manusia dan karena itu pula budaya dapat dirubah. Dalam asumsi penulis, aplikasi keagamaan perlu dilakukan dalam situasi kekinian. penafsiran konsep atau teks, perlu disesuaikan dengan masa saat ini. Dalam situasi ini,para tokoh agama sangat berperan penting dalam memberikan ajaran terhadap masyarakat. Selain itu para tokoh agama juga harus mampu melakukan pendekatan budaya. peranan tokoh agama bisa memuaskan segala pihak yang terlibat.

\section{REFERENSI}

Kementrian pemberdayaan perempuan dan perlindungan anak. (2017). Mengenal Kekerasan terhadap perempuan dan anak. Jakarta : Kementerian Pemberdayaan Perempuan dan Perlindungan Anak.

Ahsinin, adzkar. diyah stiawati. Fr. Yohana Tantria Wardhani. Prof. Dr. Sulistiyowati Irianto. MAVeronica,SH.,MA.Mencegah dan Menangani Kekerasan Seksual terhdap Perempuan dan Anak di Lingkungan Pendidikan.

Maknun,lulu'il.(2016). Kekerasan terhadap anak oleh orang tua yang stres. Jakarta:UIN Syarif Hidayatullah.

kandedes, lin. (2020). Kekerasan terhadap anak dimasa pandemi covid19 .Jakarta : UIN Syarif Hidayatullah.

Hasbi, Muhammad. (2017). kekerasan terhadap perempuan menurut tinjauan agama dan sosiologi. Watampone : STAIN watampone.

Hana, lidwina.(2016).'Kasus Pemerkosaan dan Pembunuhan Yuyun dalam Kacamata Kultur Patriarki". Jurnal studi kultural volume 1 ( hal 126) Komnas perempuan. 15 bentuk kekerasan seksual.

Kementerian Pemberdayaan Perempuan dan Perlindungan Anak. Mengakhiri kekerasan terhadap perempuan dan anak di Indonesia.

Hidayat, fahri.(2015). "Pengembangan Paradigma Integrasi Ilmu: Harmonisasi Islam dan Sains dalam Pendidikan", Jurnal pendidikan Islam Volume 4 ( Hal. 317).

Hidayat, fahri. (2019). "Perspektif Peneliti Outsider Terhadap Perilaku Keagamaan Masyarakat Muslim (Kajian pada Pemikiran Frederick M. Denny)". Jurnal studi islam volume 14 ( Hal 111). 